\title{
Analysis of influential factors affecting workers' productivity on highway construction projects during Covid-19 pandemic in Cagayan Valley Region, Philippines
}

\author{
Emer Tucay Quezon ${ }^{1, *}$ and Arthur G. Ibanez ${ }^{2}$ \\ ${ }^{1}$ Department of Management \& Allied Areas, School of Graduate Studies, IIC University of Technology, Phnom Penh, \\ Kingdom of Cambodia, and GRADXS, India. \\ ${ }^{2}$ Department of Civil Engineering, School of Engineering, Cagayan State University, Carig Campus, Tuguegarao City 3500, \\ Cagayan Valley Region, Philippines.
}

Global Journal of Engineering and Technology Advances, 2021, 06(02), 074-089

Publication history: Received on 09 January 2021; revised on 10 February 2021; accepted on 12 February 2021

Article DOI: https://doi.org/10.30574/gjeta.2021.6.2.0019

\begin{abstract}
In highway construction projects, labor-oriented work is an integral part of the management process, requiring analysis of factors affecting labor productivity during Covid-19 pandemic. This research identified 53 influential factors affecting construction labor productivity at selected cities and towns in Cagayan Valley Region, Philippines. Due to the pandemic, the construction industries incurred substantial profit losses. More so, the construction workers are too much affected because of the Enhance Community Quarantine (ECQ) imposed by the local government. Results indicated there was laxity on the Covid-19 protocols. No health worker in the project site ranked the highest in the health \& safety factor group with an RII of 0.97 and ranked $1^{\text {st }}$ among 53 factors on the different groups. Besides, no safety engineer was assigned to the projects and ranked $2^{\text {nd }}$ with an RII of 0.93 . Among the 7 groups of factors, the health and safety group ranked $1^{\text {st }}$ with 0.81 , followed by the schedule compression group with an RII of 0.78 . Hence, these two groups of factors have a strong relationship, as evidenced by number of workers reduced. It was learned that the contractors' strategy was to increase the number of working days to cope with their schedules. Hypothesis testing supported that there are various significant factors influencing labor productivity loss during the Covid-19 pandemic, as suggested by more than $50 \%$ of the respondents.
\end{abstract}

Keywords: Labor productivity; Covid-19 pandemic; Enhance Community Quarantine; Health \& safety program; Schedule compression.

\section{Introduction}

It is widely recognized that an efficient highway infrastructure is a requirement for economic and social development and its importance of transport for economic growth resulting from its multilateral links with different forms of human activity [1]. Literature reviews indicated the construction labor cost comprises $12 \%$ - 30\% of the highway projects' total budget costs [2]. In construction, labor productivity has become a prominent issue in the construction industry [3]. This research's primary goal is to provide information about essential factors affecting labor productivity during the Covid19 pandemic to the construction industries' project management team, who would likely enable the project's success. This research will help augment the understanding of the essential influencing factors affecting the fluctuation of labor productivity in highway construction projects so that the construction project managers can effectively manage labor productivity, despite the pandemic's effect. Most of the projects implemented by the Department of Public Works and

\footnotetext{
* Corresponding author: Emer Tucay Quezon. E-mail: quezonet09@gmail.com

Department of Management \& Allied Areas, School of Graduate Studies, IIC University of Technology, Phnom Penh, Kingdom of Cambodia, and GRADXS, India.
} 
Highways at the District Engineering levels, Cagayan Valley Region, Philippines, suffer issues from health and safety, schedule compression issues, workforce and materials and equipment issues, including lack of empowerment for the workers, which are an indicator of labor productivity losses. Shifting of work or reassignment of work will generally affect the use of project resources, including project costs, labor, and the need for a pattern of labor control if the project is delayed or accelerated [4]. Through literature review, only a few studies were conducted on worker productivity in highway construction, but none at all in the northern part of the Philippines to explore extensively with a similar study during the Covid-19 pandemic using a hypothesis-testing technique. Labor productivity is the most crucial aspect that influences any construction firm's performance in any country [5]. Optimized labor productivity is an essential aspect of any construction organization, but this pandemic time is impossible to obtain. The assessment of labor-oriented works in construction projects is an integral part of the management process to know the strengths and weaknesses [6]. There are a lot of influencing factors affecting labor productivity in the construction industry. A study conducted by [7] ranked the factors affecting labor productivity in Trinidad and Tobago. It was reported that lack of labor supervision is the most influencing labor productivity factor for productivity losses, followed by unrealistic scheduling, shortage of experienced-skilled laborers. Likewise, other literature reviews explained that those influencing factors are relatively encountering low productivity, price escalation, behind schedule activities, and decreased profit margins. According to [8] to mitigate such problems and enhance profitability, contractors should implement the technical procedures to improve construction labor productivity.

While, according to $[9,10]$ it is challenging to enhance productivity without improving work-performing methods. There are various techniques for measuring total work performed; however, these techniques are not specific to construction industries. The main goal of each organization is to achieve higher productivity. It sets the foundation for cost-saving [11] and plays a crucial role in the accurate scheduling and financial success of a construction project [12]. Hence, this research study tried to fill the gap so that the managers from the construction industry would be able to be clarified how the worker's productivity plays a major role to the performance of every project that they are going to be implemented during or after the pandemic period.

\section{Study Area and Research Methods}

\subsection{Study area}

Two cities and two towns are selected for the study: Tuguegarao City, Ilagan City, Delfin Albano, and Tumauini. Cagayan Valley Region is approximately $238.2 \mathrm{~km}$ via R-8 and Pan-Philippine Hwy/AH26 from Manila to the Dalton Pass, the boundary between Cagayan Valley Region and Region III. The regional center is located in Tuguegarao City, a seat of all the different agencies' Regional Offices. It is one of the business hubs in the northern part of the Philippines and about 480 kilometers away from Manila, the capital of the Republic of the Philippines.
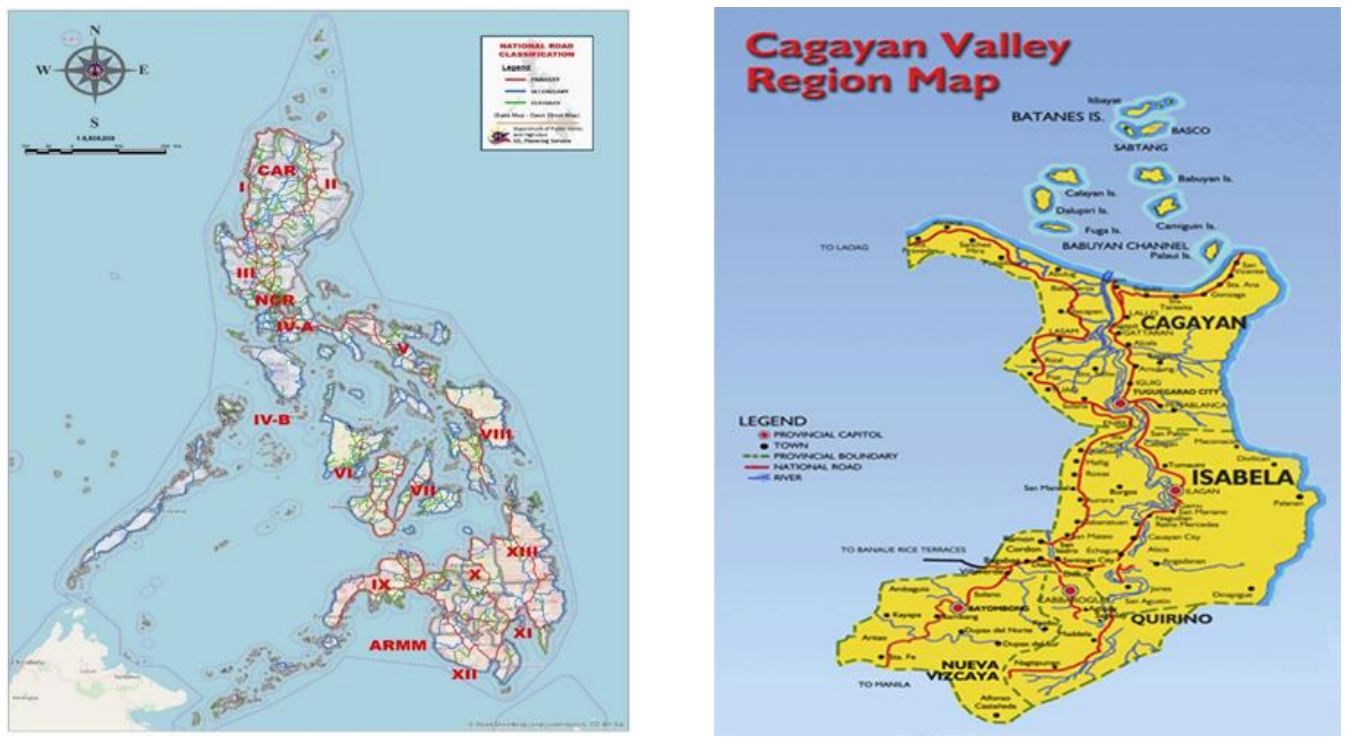

Figure 1 Map of the Study Area (Source: Google map 2021) 


\subsection{Research Methods}

The primary data were identified as being relevant to the effectiveness of the conduct of this research. It was obtained using a well-structured questionnaire developed from the initial identification of likely influencing factors affecting labor efficiency in the study area and suggestions to minimize the effect. The questionnaire format designed to elicit information on the following: The respondent's role in construction, the respondent's professional background, an analysis of the severity of likely influencing factors affecting labor efficiency from strongly disagree to strongly agree, and an analysis and evaluation of the factors causing low construction productivity. On the other hand, the secondary data was conducted through the review of various related literature. All factors are assigned nominal and ordinal scales for choices. The questionnaires are developed and validated before being distributed to all target respondents.

\subsubsection{Population of the study}

Population refers to all the respondents who will meet the particular criterion specified for research analysis. The study population consisted of various projects employed the project managers, project engineers, resident engineers, and foremen from the Contractors and the District Engineering personnel. The target population included in the study composed of all participating technical personnel of the Department of Public Works \& Highways at Cagayan 3rd District Engineering, Tuguegarao City, Isabela 1st District Engineering, and contractors directly involved in road construction implementation, and the contractors from the two towns of Delfin Albano and Tumauini, Isabela. Preliminary surveys, interviews, and data collections from the district engineering offices and contractors, there were 27 projects as the study's target population.

\subsubsection{Sampling technique and Sample size Determination}

The random sampling technique was employed so that the population's representativeness can ensure the analysis's reliability. All District Engineering Offices in the Cagayan Valley Region of the Department of Public Works and Highways are mandated to implement national infrastructure projects such as Portland Cement Concrete Pavement (PCCP), Bituminous Concrete Hot-laid (asphalt) pavement, Flood Control, and Public Building projects within their area of jurisdiction. The DPWH Regional Office 02 is mandated to prepare the plans, design, and construction, including monitoring all local infrastructure projects within the region implemented by 11 District Engineering Offices. To date, there are various highway concreting works, major flood control projects, and various road projects below Php10 million project costs implemented by the two selected district engineering offices. There were three participating organizations in the project's implementation: the District Engineering Offices (implementing office) as the clients and the Contractors. There were sixteen contractors within the study area directly involved in road projects, aside from those contractors from the entire Cagayan Valley Region, which was considered for the study. The respondent's sample size was calculated using the following equation for a $94 \%$ confidence level $[13,14]$ :

$\mathrm{n}=\mathrm{n}^{\prime} /\left[1+\left(\mathrm{n}^{\prime} / \mathrm{N}\right)\right]$

Where: $\mathrm{n}=$ total number of population; $\mathrm{N}=$ sample size from a finite population

$\mathrm{n}^{\prime}=$ sample size from an infinite population, $\mathrm{n}^{\prime}=\mathrm{S} 2 / \mathrm{V} 2$

$\mathrm{S} 2=$ variance of the elements in the population, and

$\mathrm{V}=$ standard error of the sampling population. (Usually, $\mathrm{S}=0.5$, and $\mathrm{V}=0.06$ )

Hence, $n^{\prime}=S 2 / V 2=(0.5) 2 /(0.06) 2=69.44$

From equation 3.1, for $\mathrm{N}=27$; hence, $\mathrm{n}=69.44 /[1+(69.44 / 27)]=19.44$ say 20 projects

To achieve the $94 \%$ confidence level, it was computed to send the questionnaires to 20 projects.

Table 1 A sample size of respondents and its distribution

\begin{tabular}{|c|c|c|c|c|c|c|}
\hline Organization & $\begin{array}{l}\text { No. of } \\
\text { Organization }\end{array}$ & $\begin{array}{l}\text { No of } \\
\text { Projects }\end{array}$ & $\begin{array}{l}\text { No. of Project } \\
\text { Managers }\end{array}$ & $\begin{array}{l}\text { No. of } \\
\text { Project } \\
\text { Engineers }\end{array}$ & $\begin{array}{l}\text { No. of } \\
\text { Resident } \\
\text { Engineers }\end{array}$ & $\begin{array}{l}\text { No. of } \\
\text { Foreman }\end{array}$ \\
\hline District Offices & 2 & \multirow{2}{*}{20} & 2 & 3 & 4 & 4 \\
\hline Contractors & 16 & & 4 & 6 & 8 & 32 \\
\hline Total & 18 & & 6 & 9 & 12 & 36 \\
\hline \multicolumn{2}{|l|}{ In percent (out of 63) } & & $9.52 \%$ & $14.28 \%$ & $19.05 \%$ & $57.15 \%$ \\
\hline \multicolumn{2}{|l|}{ Total No. of Respondents } & & \multicolumn{4}{|l|}{63} \\
\hline
\end{tabular}




\subsubsection{Validity test measure and Reliability test measure}

According to [15], any study based on measurement must be concerned with reliability. Reliability is concerned with the fact that the data collection and analysis procedures always produce the same results. Others can also make similar observations and arrive at the same findings from the same raw data. In other words, it is an attribute in which data collection procedures can be replicated with the same results. Cronbach's Alpha ( $\alpha$ ) was developed [15] to measure the internal consistency or scale; it is always supposed to fall between 0 and 1 . This measurement method was created in a framework where a series of questions are posed to individuals to measure a particular definition. Internal consistency is described as the degree to which all questions contribute positively to measuring the same concept or structure and, therefore, are linked to the objects' interconnection. Accordingly, Cronbach's Alpha $(\alpha)$ refers to the internal consistency as the proportion of the test variance due to a group of things calculating the alpha reliability coefficient $[16,17]$.

$\propto=\frac{I}{I-1}\left(1-\frac{\sum_{i=1}^{I} \sigma_{I}^{2}}{\sigma_{X}^{2}}\right)$

Where: $I=$ Number of Items; $\sigma_{I}^{2}=$ variant items; $\sigma_{X}^{2}=$ total score variant

A high value of Cronbach's Alpha means a higher internal accuracy of the build $\sigma \mathrm{X}^{2}$. The higher the coefficient, the greater the items' linear relationship is associated with, the higher internal consistency [15]. From [16] provides the following rules of thumb: $\geq 0.9$ (Excellent), $\geq 0.8$ (Good), $\geq 0.7$ (Acceptable), $\geq 0.6$ (Questionable), $\geq 0.5$ (Poor), and $\leq 0.5$ (Unacceptable). Although increasing Alpha's value is partially dependent upon the number of things in the scale, it could be noted that this has diminishing returns [17]. Cronbach's alpha-coefficient is the most commonly used objective indicator of reliability. The internal accuracy of the data reliability scale obtained from the questionnaire was tested with this coefficient before further analysis proceeded in this study. The findings are, therefore, consistent.

\subsubsection{Relative Importance Index}

The Relative Importance of variables in highway construction work productivity was used to rank the different factors. The approach was applied in this study within the respondents' groups (i.e., clients and Contractors). For each variable, the five-point scale 1, 2, 3, 4, and 5 are assigned to measure the relative importance index to determine the relative rank. Table 2 shows the scale with corresponding ordinal, adjectival rating and description.

Table 2 A rating scale for factors influencing worker's productivity

\begin{tabular}{|c|l|}
\hline Ordinal number & Description \\
\hline 1 & Strongly disagree \\
\hline 2 & Don't agree \\
\hline 3 & Neutral \\
\hline 4 & Agree \\
\hline 5 & Strongly agree \\
\hline
\end{tabular}

The data obtained from the questionnaires are evaluated using the Relative Importance Index (RII). The RII is determined based on frequency to analyze the rating and practicability of each performance measure. The Relative Importance Index (RII) is estimated using the formula for various factors [18-19].

$R I I=((5 n 5+4 n 4+3 n 3+2 n 2+n)) /(5(n 5+n 4+n 3+n 2+n))$

Where: RII = Relative Importance Index

$\mathrm{n} 5, \mathrm{n} 4, \mathrm{n} 3, \mathrm{n} 2$ \& n= Number of indicators of answer

The calculation with the formula of the Relative Importance Index provides the RII value between 0.2 and 1.0. The 0.2 values represent the lowest strength, and the 1.0 value the highest strength. The data obtained from field surveys and desk studies are qualitatively analyzed and evaluated, and interpreted. 


\subsubsection{Hypotheses Testing}

Hypothesis testing was used as a supporting tool for this study concerning the data's analysis and interpretation. Population proportions are often made in the context of the probability (p) of success for a binomial distribution [19].

Z= (Sample Proportion - Null hypothesized proportion)/(standard deviation of Sample Proportion)

The rejection region \& its interpretation: When Ha: $\mathrm{p} \neq$ po. Reject Ho if $\mathrm{T}$ is greater than $\mathrm{Z}_{0.025}=1.96$ or less than -1.96 . The test is accomplished using equation (4). The test results are shown in Table 5. All the T-values higher than 1.96 indicated significant influencing factors affecting labor productivity in highway construction in the study area. Testing of Ho: $p=0.50$ vs. Ha: $p \neq 0.50$, where $p$ represents that the proportion of respondents who suggested the influencing factor affects labor productivity is significant or non-significant.

\section{Results and discussion}

\subsection{Statistical data of questionnaires distributed and collected}

There were 63 questionnaires distributed to the respondents, and only 55 returned with complete information and answers, while questionnaires returned with incomplete answers, which are invalid and not considered for the analysis. Table 3 shows the statistical data of questionnaires distributed and collected.

Table 3 Statistical data of questionnaires distributed and collected

\begin{tabular}{|l|l|l|}
\hline Description & No. & Percentage of Total (\%) \\
\hline Total questionnaires distributed & 63 & $100.00 \%$ \\
\hline Total questionnaires collected & 55 & $87.30 \%$ \\
\hline Invalid data & 8 & $12.70 \%$ \\
\hline Used for study & 55 & $87.30 \%$ \\
\hline
\end{tabular}

\subsection{Job Title}

Table 4 indicated the job title and the number of respondents. They were all contacted and distributed the questionnaires providing complete answers based on the questionnaire's format and instructions.

Table 4 Job Title of the Respondent

\begin{tabular}{|l|l|}
\hline Job Title of the Respondents & Number of Respondents \\
\hline Project Managers & 4 \\
\hline Project Engineers & 7 \\
\hline Resident Engineers & 10 \\
\hline Foremen & 34 \\
\hline $\begin{array}{l}\text { Total number of respondents with } \\
\text { questionnaire collected, thoroughly } \\
\text { answered }\end{array}$ & 55 \\
\hline
\end{tabular}

\subsection{Major Factors Influencing Construction Labor Efficiency}

The influencing factors affecting highway construction projects' labor efficiency were grouped and categorized according to their similarity. Groups of factors that have a high effect on highway construction are described below. Fifty-three identified factors influencing labor productivity for road construction projects, and their corresponding Relative Importance Index (RII) was calculated using the equation (3.3). These factors were classified into seven groups such as (1) management factor, (2) workforce, (3) supervision, (4) schedule compression, (5) materials \& equipment, (6) health \& safety, and (7) motivation. The groups of factors are discussed in detail. 


\subsubsection{Management factor}

Figure 2 indicated the ranking factors for the management team factor. Poor relations between labor supervisor was ranked first in the management team factor, with a relative importance index of 0.85 , and was eight among all 53 factors affecting labor productivity as indicated in figure 10. Lack of labor surveillance was ranked 2 nd in the management team group, with a relative importance index of 0.81 , and 12th among all 53 factors affecting labor productivity. Poor communication \& coordination ranked 3rd and the last one under the management team group, with an RII of 0.51, and 32nd among all 53 factors affecting labor productivity in this study.

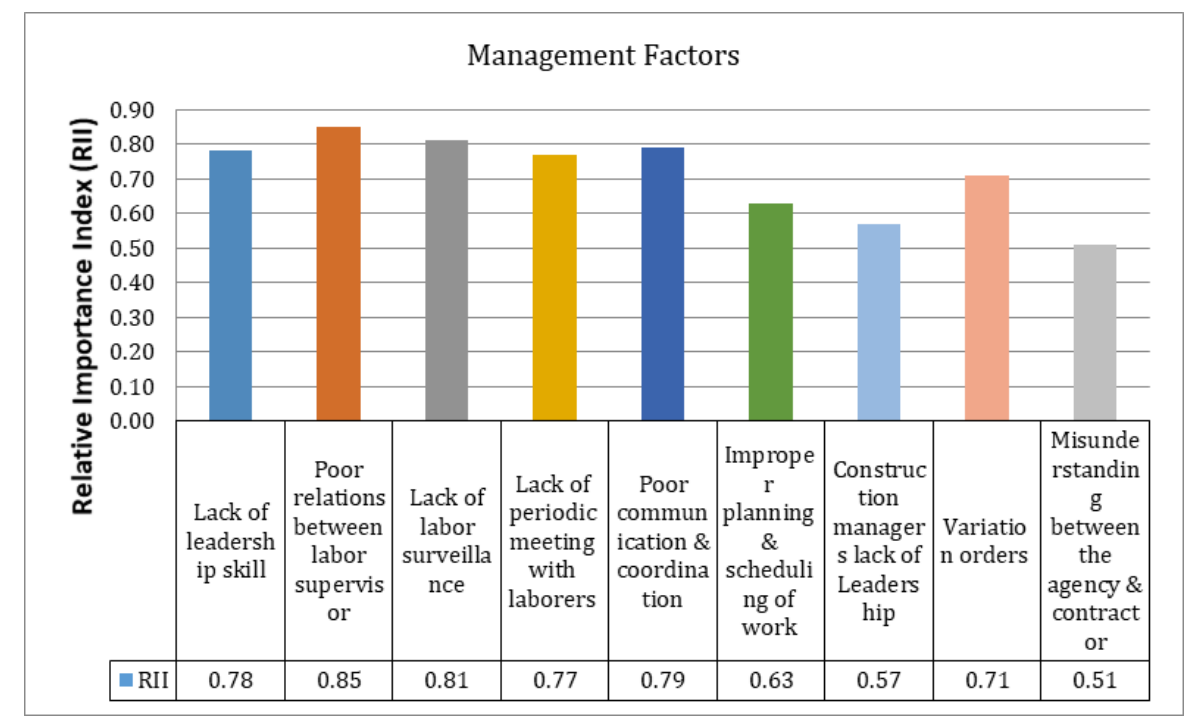

Figure 2 Management team factors

\subsubsection{Workforce factor}

Figure 3 shows the ranking for factors of the Workforce factor group. The Workforce's negative effect on labor productivity can be seen in laborers' absenteeism due to health issues, ranked 2nd in the factor group, with an RII of 0.85, which is ranked 8th among all 53 factors. However, lack of labor empowerment such as training and seminar ranked 1st with an RII of 0.89 , significantly influencing productivity, ranked 4th from all 53 factors. Low laborer's morals and commitment to their works, and poor relations among workers, are ranked 3rd and 4th in the workforce group, with an RII value of 0.80 and 0.81 , respectively. The workers' poor health ranked last with an RII of 0.60 in this workforce factors and ranked 28th from all 53 factors. The increase of laborer age above 40 years ranked 7 th in the workforce group, with an RII of 0.67 , and ranked 23rd among 53 influencing factor affecting labor low productivity.

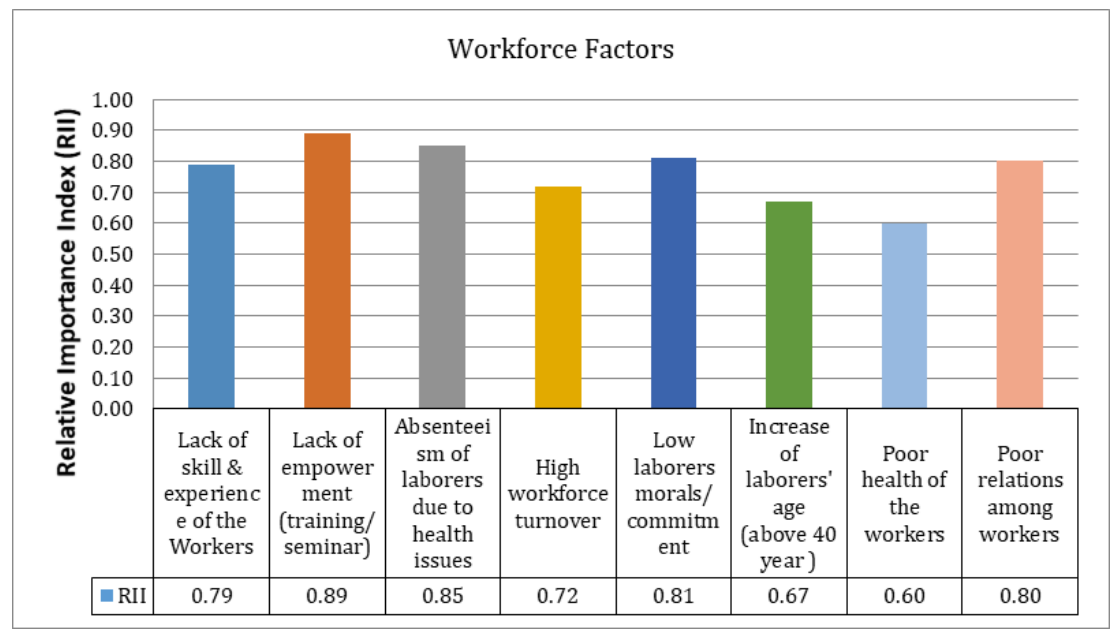

Figure 3 Workforce factors 


\subsubsection{Supervision factor}

Changing instruction order ranked 1st in the supervision group, with an RII value of 0.83 , and 10 th among all 53 influencing factors affecting labor productivity. Inspection delay ranked 2nd with an RII value of 0.78 and 15 th among all 53 factors. Poor or no supervision methods ranked 3rd with an RII of 0.71 and 19th among all 53 factors. On the other hand, supervisor's absenteeism was the last factor in this group and the last of all 53 factors. It is insignificant because it does not affect labor productivity.

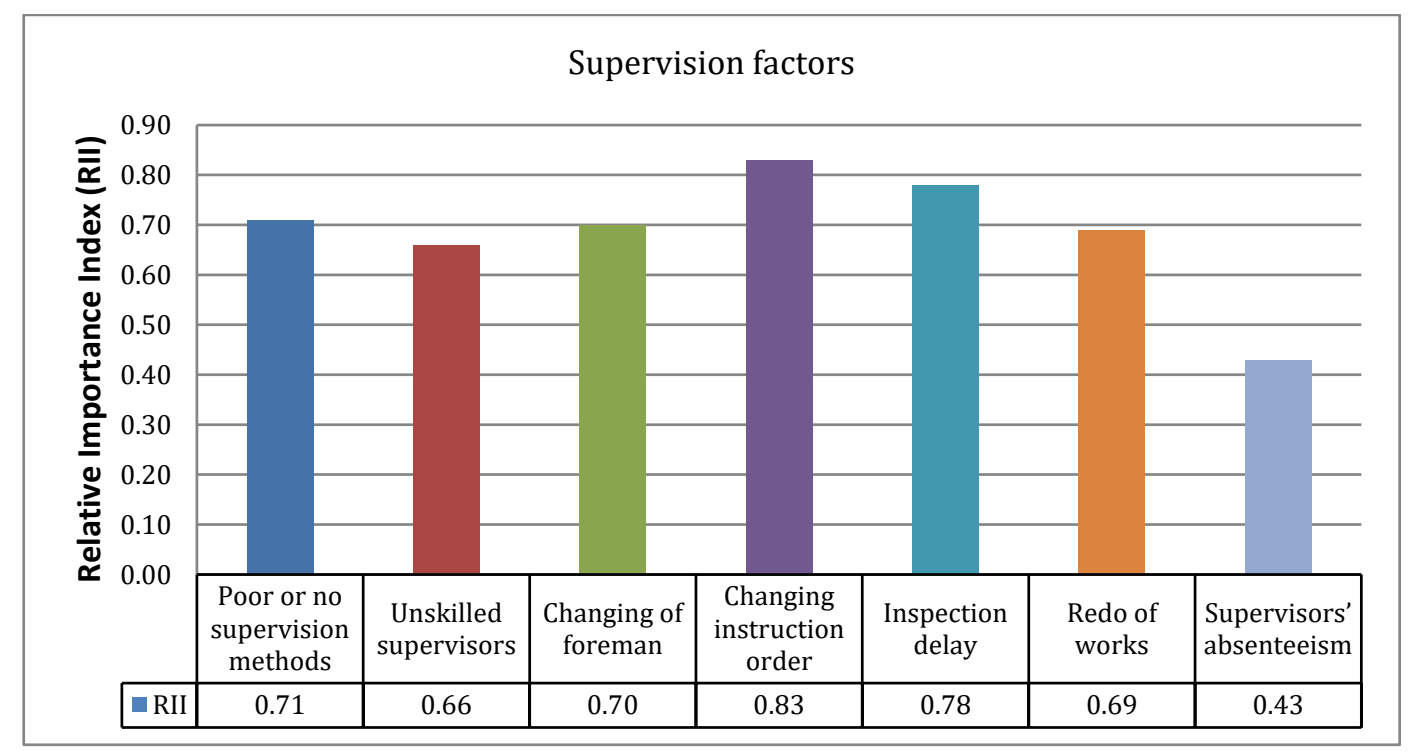

Figure 4 Supervision Factors

\subsubsection{Schedule Compression factor}

Shifting of work or reassignment of work ranked 1st in the schedule compression factor with an RII of 0.91 and ranked 3rd among all 53 influencing factors affecting labor productivity. Likewise, working six days per week ranked 2nd with an RII of 0.87. Poor work planning was ranked 3rd in the schedule compression group, with an RII value of 0.85 , and 8th among all 53 factors affecting labor productivity. While the frequency of work overtime ranked 4th in the schedule compression factor and $11^{\text {th }}$ among all 53 factors in this study. Overcrowding and overlapping of work were the last in this group of factors, and 2nd to the last among all the 53 factors. This result is insignificant as an influencing factor to the labor productivity because the employer limited the number of workers in a week due to Covid-19 pandemic.

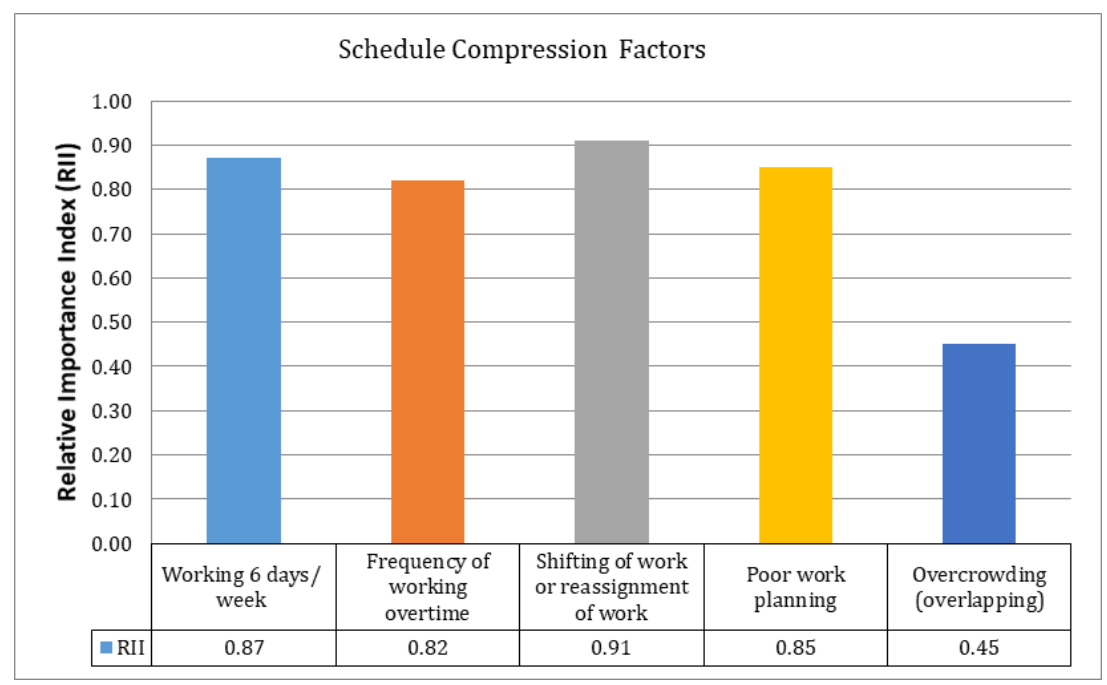

Figure 5 Schedule Compression factors 


\subsubsection{Material and Equipment Resource Factors}

Figure 6 shows that poor condition of equipment and tools ranked $1^{\text {st }}$ with an RII of 0.86 , and lack of equipment and tools ranked $2^{\text {nd }}$ with RII of 0.83 . The former one ranked $7^{\text {th }}$, while the latter one ranked $10^{\text {th }}$ among all 53 influencing factors affecting labor productivity. The result justified as significant equipment on the site, including dump trucks, transit mixer, compacting machine, water truck, and bulldozer. The entire construction process depends heavily on this equipment. Any bog down or breakdown of the equipment leads to material-handling problems as well as a slowdown or a stoppage of operations. Hence, the availability of equipment at all times is regarded as essential for construction progress. Previous studies by $[20,21]$ proved that equipment and tools were the main factors that negatively affect labor productivity in construction. Materials shortages ranked $3^{\text {rd }}$, affecting the labor productivity with an RII of 0.79 , while the poor arrangement of materials ranked the last in the material and equipment resource factors and ranked $31^{\text {st }}$ among all 53 factors.

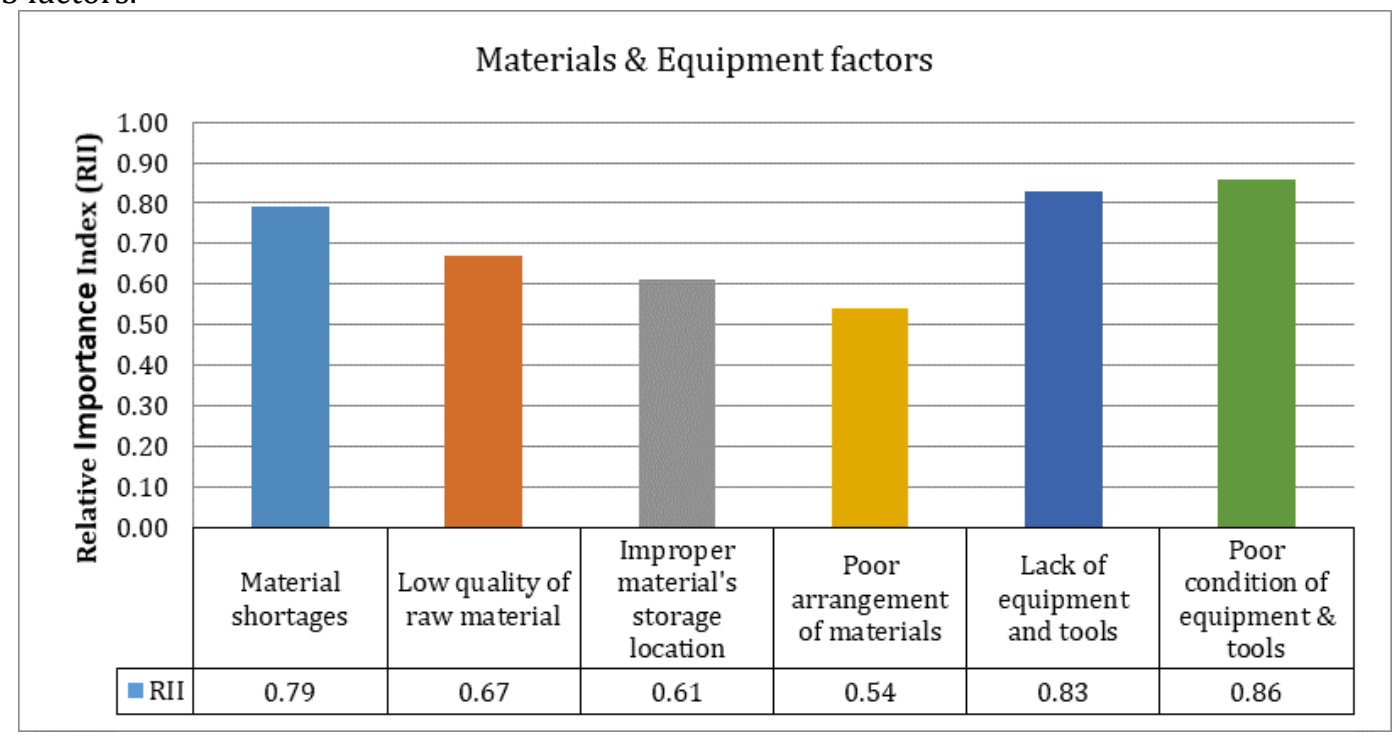

Figure 6 Materials and equipment resource factors

Although, in this study, the materials shortage ranked 3rd, and the materials and equipment resource factors at 4th position among the seven groups of factors affecting labor productivity, there was a strong influence on the labor low productivity in highway construction. This result is implicated by the limited travel time and delivery of materials from one place to another. It was in contradiction with the findings of other researchers when there was no Covid-19 pandemic.

\subsubsection{Health and Safety factor}

Figure 7 depicted the ranking factors for the health and safety group. No health worker in the project site ranked the highest in this group of the factor with an RII of 0.97 and ranked 1st among all 53 influencing factors. It means there was a laxity of the rules and regulations, including the Covid-19 protocols. In every unit or agency, it should be understood that checking the health conditions of workers before their work hours should be tested. Another alarming result, there was no safety engineer assigned in the projects and ranked 2nd with an RII of 0.93, followed by a lack of labor safety standard with an RII of 0.88. Since the Covid-19 pandemic started, Cagayan Valley Region authorities tried their best to manage the health and safety issues by imposing Enhanced Community Quarantine (ECQ) of at least 14 days for those towns and cities with individuals affected by the pandemic. Improper observance of Covid-19 protocols ranked 5th in these health and safety factors. It proves this factor that there was a strong inter-relationship with no health workers in the project site. As it could be seen, all of these health and safety factors have a strong influence the labor low productivity. 


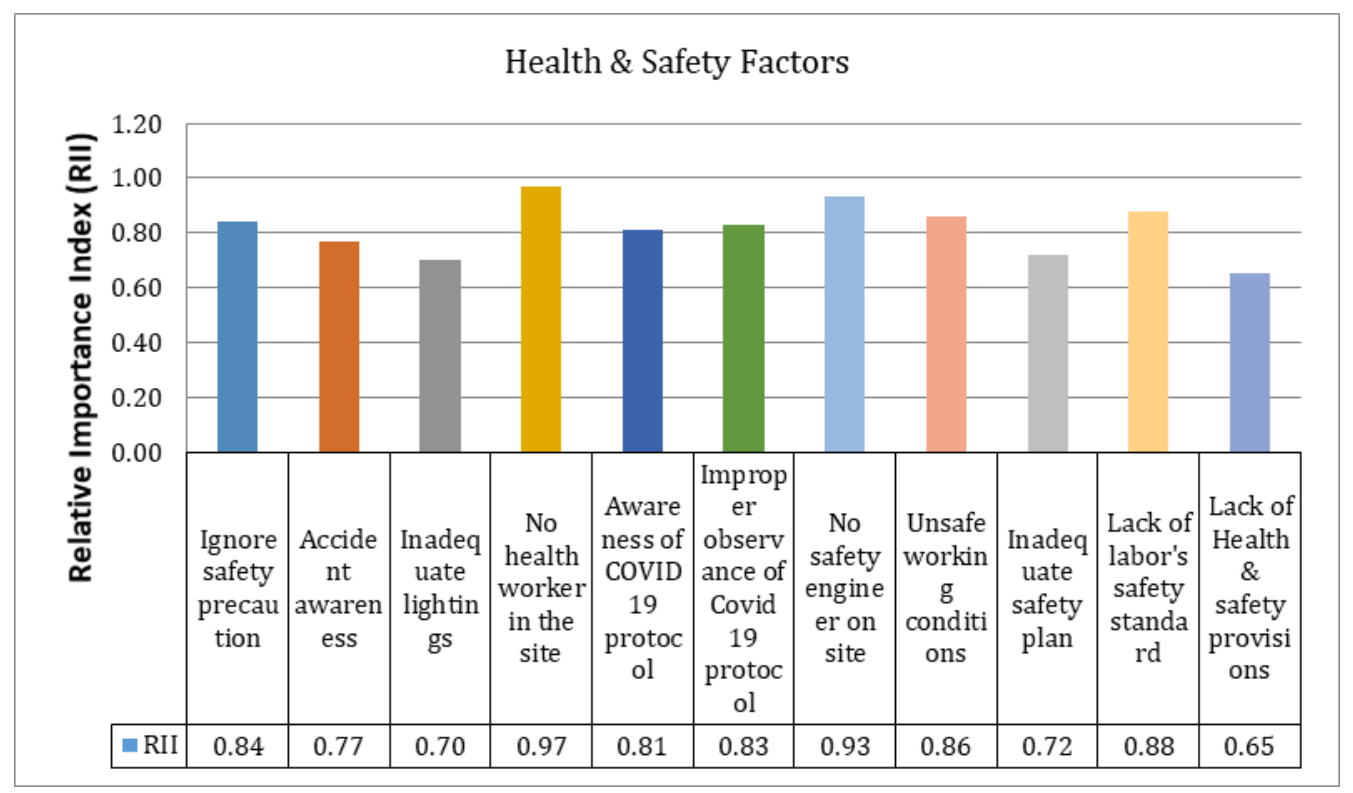

Figure 7 Health and safety factors

\subsubsection{Motivation factor}

Underpaid workers ranked 1st in the motivation group, with an RII value of 0.75 , and the 17 th among all 53 influencing factors affecting labor productivity as indicated in figure 10. The most affected on this factor is on the contractor's side because of declining operations due to Covid-19 patients' increasing cases in some areas in the region. Lack of labor recognition program ranked 2 nd in this group and 18th among all the 53 factors. The lowest among the motivation factor was no security of tenure.

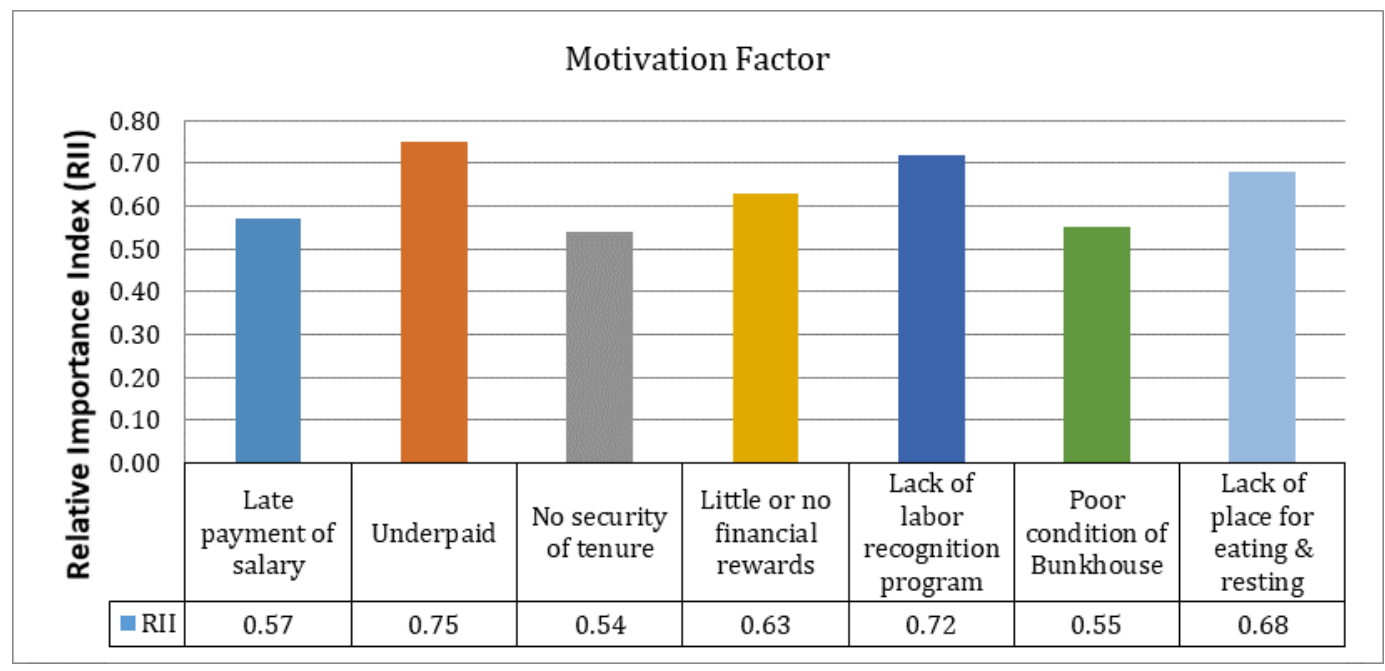

Figure 8 Motivation factors

\subsubsection{Group of Factors Affecting Labor Low Productivity}

Figure 9 shows the seven groups of factors affecting labor low productivity. It was calculated by considering the average RII value for all the factors that affect labor productivity in a highway construction project. Among all seven groups of factors, health and safety issues ranked 1st with RII 0.81 . The schedule compression ranked 2nd with an RII of 0.78 , followed by a workforce group of factors with an RII of 0.77 . The first three groups of factors indicated low construction labor productivity in the entire study area in Cagayan Valley Region due to the pandemic. It is prevalent that all construction industries worldwide are affected by the Covid-19 pandemic, specifically the labor sectors. The health department protocol is very stringent. 


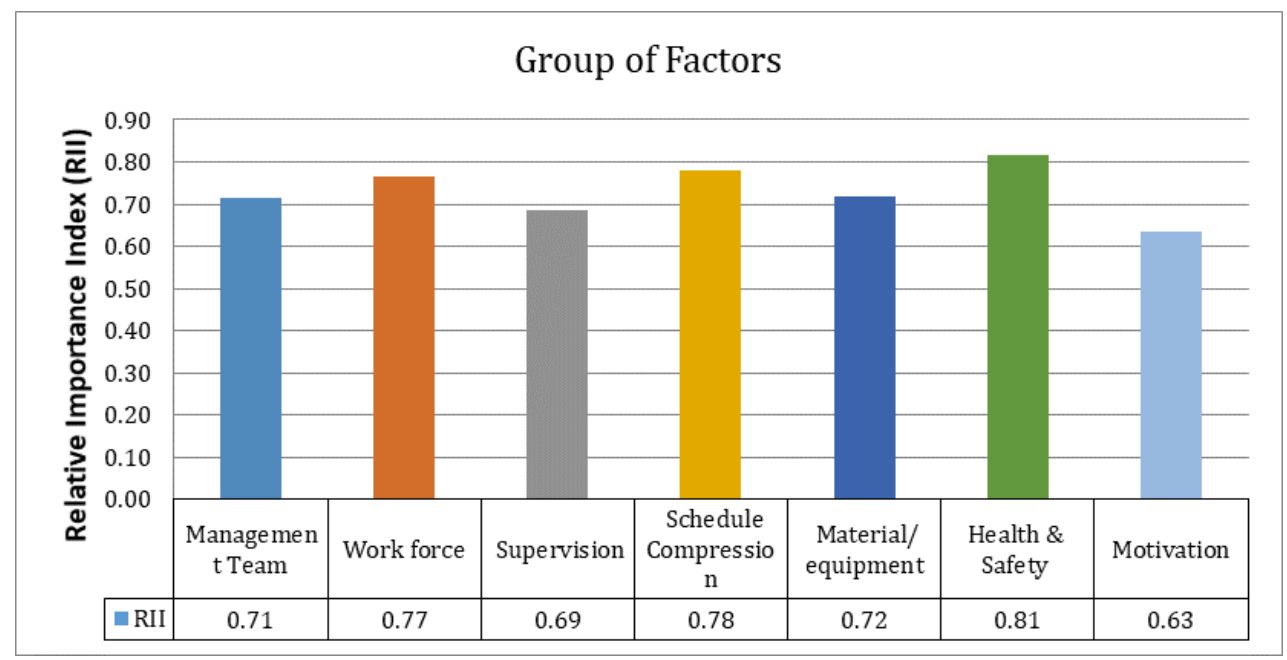

Figure 9 Groups of influencing factors affecting labor productivity

Figure 10 shows the ranking of all 53 influencing factors affecting labor productivity used in the study to analyze their effects during the Covid-19 pandemic at the selected cities and towns in the Cagayan Valley Region, Philippines.

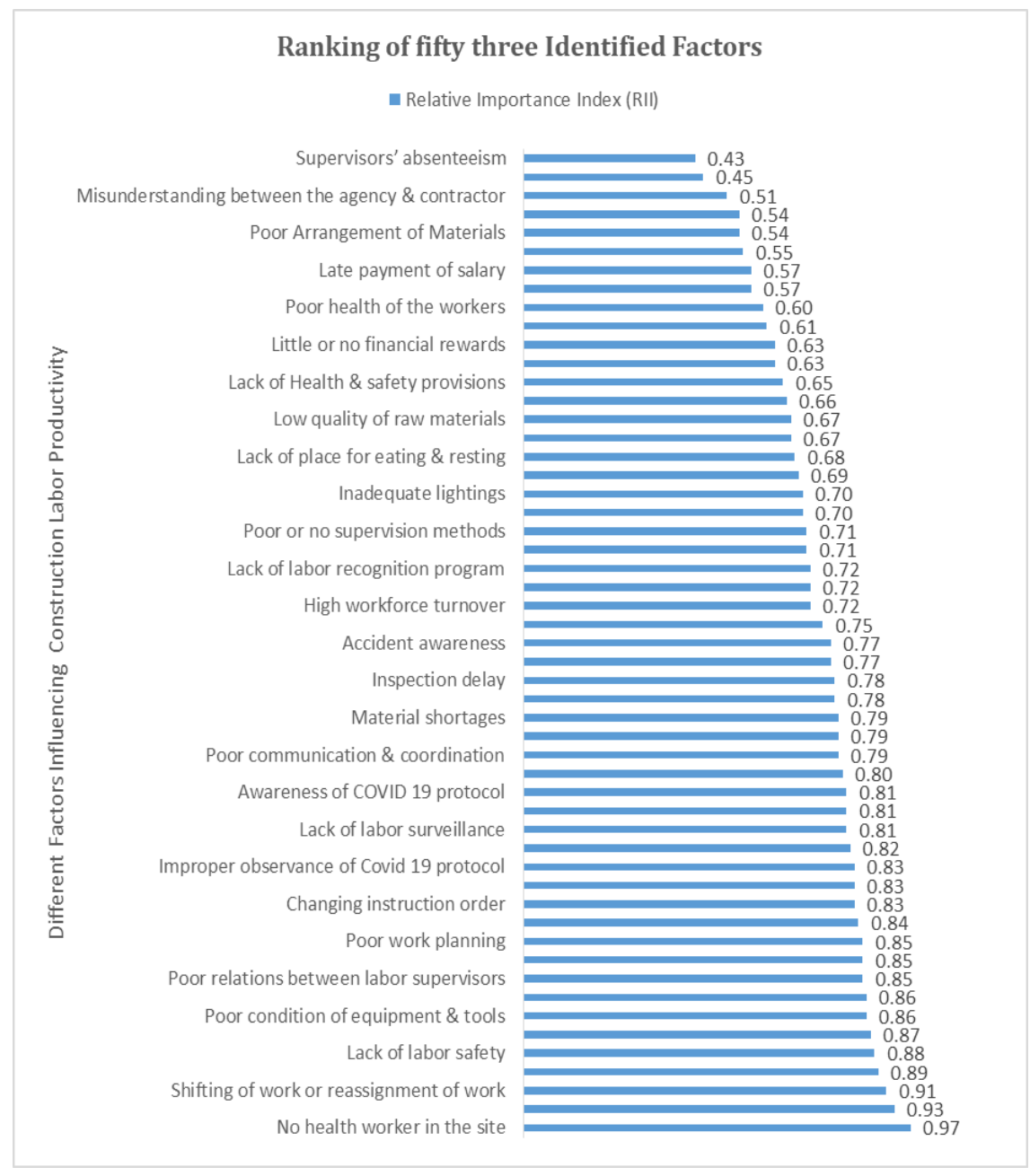

Figure 10 Ranking of all factors used in the study 


\subsubsection{Results of hypotheses testing and analysis}

Table 5 indicated the hypothesis testing results to support the findings of the study. This was to identify the significant and non-significant factors affecting the highway construction labor low productivity during Covid-19 pandemic. The rejection region and its interpretation as follows: when Ha: $p \neq$ po. Reject Ho if $\mathrm{T}$ is greater than $\mathrm{Z}_{0.025}=1.96$ or less than -1.96. The test performed using equation (4). All the T-values that are higher than 1.96 indicated that there are significant influencing factors affecting labor productivity in highway construction in the study area. Testing of Ho: $\mathrm{p}=$ 0.50 vs. Ha: $p \neq 0.50$, where $p$ represents that the proportion of respondents who suggested the influencing factor affects labor productivity is significant or non-significant.

Results depicted that the top 8 influencing factors out of 53 factors affecting labor productivity with T-values ranging from 3.48 to 4.80. These are no health worker on-site, no safety engineer, lack of empowerment for laborers, working six days per week, frequent working overtime, sifting of work or reassignment of work, poor condition of equipment \& tools, and lack of laborer's safety standard. It means that more than $50 \%$ or a majority of respondents suggested that significant factors were affecting labor low productivity during the pandemic. These results reconciled with the ranking factors' results using the Relative importance index from the preceding results of a group of influencing factors in labor productivity.

Table 5 Hypotheses Testing to Identify Significant and Non-Significant Factors.

\begin{tabular}{|c|c|c|c|c|c|c|}
\hline \multirow[b]{2}{*}{ No. } & \multirow{2}{*}{$\begin{array}{l}\text { Influencing factors } \\
\text { affecting construction } \\
\text { labor low productivity }\end{array}$} & \multicolumn{4}{|c|}{ Hypothesis Testing } & \multirow[b]{2}{*}{ Remarks } \\
\hline & & Alt. & Null & $\begin{array}{l}\text { Std. } \\
\text { Dev. }\end{array}$ & $\begin{array}{l}\text { T-Value } \\
\text { Results }\end{array}$ & \\
\hline \multicolumn{7}{|c|}{ I. Management team factors } \\
\hline 1 & Lack of leadership skill & 85.71 & 14.29 & 1.07 & $\begin{array}{l}3.33 \\
\text { T-rejected }\end{array}$ & $\begin{array}{l}\text { More than } 50 \% \text {, suggests } \\
\text { significant factor affecting labor } \\
\text { productivity }\end{array}$ \\
\hline 2 & $\begin{array}{l}\text { Poor relations between } \\
\text { labor supervisors }\end{array}$ & 83.00 & 17.00 & 1.27 & $\begin{array}{l}2.59 \\
\text { T-rejected }\end{array}$ & $\begin{array}{l}\text { More than } 50 \% \text {, suggests } \\
\text { significant factor affecting labor } \\
\text { productivity }\end{array}$ \\
\hline 3 & Lack of labor surveillance & 90.00 & 10.00 & 1.07 & $\begin{array}{l}3.75 \\
\text { T-rejected }\end{array}$ & $\begin{array}{l}\text { More than } 50 \% \text {, suggests } \\
\text { significant factor affecting labor } \\
\text { productivity }\end{array}$ \\
\hline 4 & $\begin{array}{l}\text { Lack of periodic meeting } \\
\text { with laborers }\end{array}$ & 83.00 & 17.00 & 1.10 & $\begin{array}{l}2.99 \\
\text { T-rejected }\end{array}$ & $\begin{array}{l}\text { More than } 50 \% \text {, suggests } \\
\text { significant factor affecting labor } \\
\text { productivity }\end{array}$ \\
\hline 5 & $\begin{array}{l}\text { Poor communication \& } \\
\text { coordination }\end{array}$ & 80.00 & 20.00 & 1.13 & $\begin{array}{l}2.65 \\
\text { T-rejected }\end{array}$ & $\begin{array}{l}\text { More than } 50 \% \text {, suggests } \\
\text { significant factor affecting labor } \\
\text { productivity }\end{array}$ \\
\hline 6 & $\begin{array}{l}\text { Improper planning \& } \\
\text { scheduling of work }\end{array}$ & 58.00 & 42.00 & 1.09 & $\begin{array}{l}0.73 \\
\text { T-not rejected }\end{array}$ & $\begin{array}{l}\text { Non-significant factor affecting } \\
\text { labor productivity }\end{array}$ \\
\hline 7 & $\begin{array}{l}\text { Construction managers } \\
\text { lack Leadership }\end{array}$ & 60.00 & 40.00 & 1.19 & $\begin{array}{l}0.84 \\
\text { T-not rejected }\end{array}$ & $\begin{array}{l}\text { Non-significant factor affecting } \\
\text { labor productivity }\end{array}$ \\
\hline 8 & Variation orders & 77.00 & 23.00 & 1.23 & $\begin{array}{l}2.20 \\
\text { T-not rejected }\end{array}$ & $\begin{array}{l}\text { More than } 50 \% \text {, suggests } \\
\text { significant factor affecting labor } \\
\text { productivity }\end{array}$ \\
\hline 9 & $\begin{array}{l}\text { Misunderstanding } \\
\text { between the agency \& } \\
\text { contractor }\end{array}$ & 33.00 & 67.00 & 1.15 & $\begin{array}{l}-1.48 \\
\text { T-not rejected }\end{array}$ & $\begin{array}{l}\text { Non-significant factor affecting } \\
\text { labor productivity }\end{array}$ \\
\hline \multicolumn{7}{|c|}{ II. Workforce factors } \\
\hline 10 & $\begin{array}{l}\text { Lack of skill and } \\
\text { experience of Laborers }\end{array}$ & 81.00 & 19.00 & 1.07 & $\begin{array}{l}2.89 \\
\text { T-rejected }\end{array}$ & $\begin{array}{l}\text { More than } 50 \% \text {, suggests } \\
\text { significant factor affecting labor } \\
\text { productivity }\end{array}$ \\
\hline
\end{tabular}




\begin{tabular}{|c|c|c|c|c|c|c|}
\hline 11 & $\begin{array}{l}\text { Lack of empowerment } \\
\text { (training/Seminar) }\end{array}$ & 103.57 & -3.57 & 1.20 & $\begin{array}{l}4.46 \\
\text { T-rejected }\end{array}$ & $\begin{array}{l}\text { More than } 50 \% \text {, suggests } \\
\text { significant factor affecting labor } \\
\text { productivity }\end{array}$ \\
\hline 12 & Absenteeism of laborers & 90.00 & 10.00 & 1.32 & $\begin{array}{l}3.04 \\
\text { T-rejected }\end{array}$ & $\begin{array}{l}\text { Non-significant factor affecting } \\
\text { labor productivity }\end{array}$ \\
\hline 13 & High workforce turnover & 35.71 & 64.29 & 1.26 & $\begin{array}{l}-1.14 \\
\text { T-not rejected }\end{array}$ & $\begin{array}{l}\text { Non-significant factor affecting } \\
\text { labor productivity }\end{array}$ \\
\hline 14 & $\begin{array}{l}\text { Low labor } \\
\text { morales/commitment }\end{array}$ & 82.00 & 18.00 & 1.18 & $\begin{array}{l}2.71 \\
\text { T-rejected }\end{array}$ & $\begin{array}{l}\text { More than } 50 \% \text {, suggests } \\
\text { significant factor affecting labor } \\
\text { productivity }\end{array}$ \\
\hline 15 & $\begin{array}{l}\text { Increase of laborer age } \\
\text { (above } 40 \text { years) }\end{array}$ & 25.00 & 75.00 & 1.19 & $\begin{array}{l}-2.10 \\
\text { T-not rejected }\end{array}$ & $\begin{array}{l}\text { Non-significant factor affecting } \\
\text { labor productivity }\end{array}$ \\
\hline 16 & $\begin{array}{l}\text { Poor health of the } \\
\text { workers }\end{array}$ & 67.00 & 33.00 & 1.34 & $\begin{array}{l}1.27 \\
\text { T-not rejected }\end{array}$ & $\begin{array}{l}\text { More than } 50 \% \text {, suggests } \\
\text { significant factor affecting labor } \\
\text { productivity }\end{array}$ \\
\hline 17 & $\begin{array}{l}\text { Poor relations among } \\
\text { workers }\end{array}$ & 85.00 & 15.00 & 1.26 & $\begin{array}{l}2.78 \\
\text { T-rejected }\end{array}$ & $\begin{array}{l}\text { More than } 50 \% \text {, suggests } \\
\text { significant factor affecting labor } \\
\text { productivity }\end{array}$ \\
\hline \multicolumn{7}{|c|}{ III. Supervision } \\
\hline 18 & $\begin{array}{l}\text { Poor or no supervision } \\
\text { methods }\end{array}$ & 46.43 & 53.57 & 1.36 & $\begin{array}{l}-0.26 \\
\text { T-not rejected }\end{array}$ & $\begin{array}{l}\text { Non-significant factor affecting } \\
\text { labor productivity }\end{array}$ \\
\hline 19 & Unskilled supervisors & 39.29 & 60.71 & 1.42 & $\begin{array}{l}-0.75 \\
\text { T-not rejected }\end{array}$ & $\begin{array}{l}\text { Non-significant factor affecting } \\
\text { labor productivity }\end{array}$ \\
\hline 20 & Changing of foreman & 67.00 & 33.00 & 1.16 & $\begin{array}{l}1.47 \\
\text { T-not rejected }\end{array}$ & $\begin{array}{l}\text { Non-significant factor affecting } \\
\text { labor productivity }\end{array}$ \\
\hline 21 & $\begin{array}{l}\text { Changing instruction } \\
\text { order }\end{array}$ & 79.00 & 21.00 & 0.92 & $\begin{array}{l}3.16 \\
\text { T-rejected }\end{array}$ & $\begin{array}{l}\text { More than } 50 \% \text {, suggests } \\
\text { significant factor affecting labor } \\
\text { productivity }\end{array}$ \\
\hline 22 & Inspection delay & 85.71 & 14.29 & 1.25 & $\begin{array}{l}2.87 \\
\text { T-rejected }\end{array}$ & $\begin{array}{l}\text { More than } 50 \% \text {, suggests } \\
\text { significant factor affecting labor } \\
\text { productivity }\end{array}$ \\
\hline 23 & Rework (Redo of work) & 20.00 & 80.00 & 1.24 & $\begin{array}{l}-2.43 \\
\text { T-not rejected }\end{array}$ & $\begin{array}{l}\text { Non-significant factor affecting } \\
\text { labor productivity }\end{array}$ \\
\hline 24 & $\begin{array}{l}\text { Supervisors' } \\
\text { absenteeism }\end{array}$ & 46.43 & 53.57 & 1.36 & $\begin{array}{l}-0.26 \\
\text { T-not rejected }\end{array}$ & $\begin{array}{l}\text { Non-significant factor affecting } \\
\text { labor productivity }\end{array}$ \\
\hline \multicolumn{7}{|c|}{ IV. Schedule compression factors } \\
\hline 25 & Working six days/week & 103.00 & -3.00 & 1.27 & $\begin{array}{l}4.17 \\
\text { T-rejected }\end{array}$ & $\begin{array}{l}\text { More than } 50 \% \text {, suggests } \\
\text { significant factor affecting labor } \\
\text { productivity }\end{array}$ \\
\hline 26 & $\begin{array}{l}\text { Frequency of working } \\
\text { overtime }\end{array}$ & 89.29 & 10.71 & 1.21 & $\begin{array}{l}3.26 \\
\text { T-rejected }\end{array}$ & $\begin{array}{l}\text { More than } 50 \% \text {, suggests } \\
\text { significant factor affecting labor } \\
\text { productivity }\end{array}$ \\
\hline 27 & $\begin{array}{l}\text { Shifting of work } \\
\text { (reassignment of work) }\end{array}$ & 85.71 & 14.29 & 0.90 & $\begin{array}{l}3.95 \\
\text { T-rejected }\end{array}$ & $\begin{array}{l}\text { More than } 50 \% \text {, suggests } \\
\text { significant factor affecting labor } \\
\text { productivity }\end{array}$ \\
\hline 28 & Poor work planning & 89.29 & 10.71 & 1.20 & $\begin{array}{l}3.28 \\
\text { T-rejected }\end{array}$ & $\begin{array}{l}\text { More than } 50 \% \text {, suggests } \\
\text { significant factor affecting labor } \\
\text { productivity }\end{array}$ \\
\hline 29 & $\begin{array}{l}\text { Overcrowding } \\
\text { (overlapping) }\end{array}$ & 53.57 & 46.43 & 0.98 & $\begin{array}{l}0.37 \\
\text { T-not rejected }\end{array}$ & $\begin{array}{l}\text { Non-significant factor affecting } \\
\text { labor productivity }\end{array}$ \\
\hline
\end{tabular}




\begin{tabular}{|c|c|c|c|c|c|c|}
\hline \multicolumn{7}{|c|}{ V. Material \& equipment factors } \\
\hline 30 & Material shortages & 63.00 & 37.00 & 0.50 & $\begin{array}{l}2.58 \\
\text { T-rejected }\end{array}$ & $\begin{array}{l}\text { More than } 50 \% \text {, suggests } \\
\text { significant factor affecting labor } \\
\text { productivity }\end{array}$ \\
\hline 31 & $\begin{array}{l}\text { Low quality of raw } \\
\text { materials }\end{array}$ & 77.00 & 23.00 & 1.26 & $\begin{array}{l}2.15 \\
\text { T-not rejected }\end{array}$ & $\begin{array}{l}\text { More than } 50 \% \text {, suggests } \\
\text { significant factor affecting labor } \\
\text { productivity }\end{array}$ \\
\hline 32 & $\begin{array}{l}\text { Unsuitable material } \\
\text { storage location }\end{array}$ & 66.75 & 33.25 & 1.17 & $\begin{array}{l}1.43 \\
\text { T-not rejected }\end{array}$ & $\begin{array}{l}\text { Non-significant factor affecting } \\
\text { labor productivity }\end{array}$ \\
\hline 33 & $\begin{array}{l}\text { Poor Arrangement of } \\
\text { Materials }\end{array}$ & 62.00 & 38.00 & 1.22 & $\begin{array}{l}0.98 \\
\text { T-not rejected }\end{array}$ & $\begin{array}{l}\text { Non-significant factor affecting } \\
\text { labor productivity }\end{array}$ \\
\hline 34 & $\begin{array}{l}\text { Equipment and tools } \\
\text { shortages }\end{array}$ & 83.65 & 16.35 & 1.05 & $\begin{array}{l}3.19 \\
\text { T-rejected }\end{array}$ & $\begin{array}{l}\text { More than } 50 \% \text {, suggests } \\
\text { significant factor affecting labor } \\
\text { productivity }\end{array}$ \\
\hline 35 & $\begin{array}{l}\text { Poor condition of } \\
\text { equipment \& tools }\end{array}$ & 94.00 & 6.00 & 1.23 & $\begin{array}{l}3.58 \\
\text { T-rejected }\end{array}$ & $\begin{array}{l}\text { More than } 50 \% \text {, suggests } \\
\text { significant factor affecting labor } \\
\text { productivity }\end{array}$ \\
\hline \multicolumn{7}{|c|}{ VI. Health \& safety factors } \\
\hline 36 & Ignore safety precaution & 79.78 & 20.22 & 1.09 & $\begin{array}{l}2.73 \\
\text { T-rejected }\end{array}$ & $\begin{array}{l}\text { More than } 50 \% \text {, suggests } \\
\text { significant factor affecting labor } \\
\text { productivity }\end{array}$ \\
\hline 37 & Accident awareness & 66.00 & 34.00 & 1.17 & $\begin{array}{l}1.37 \\
\text { T-not rejected }\end{array}$ & $\begin{array}{l}\text { Non-significant factor affecting } \\
\text { labor productivity }\end{array}$ \\
\hline 38 & Inadequate lightings & 42.86 & 57.14 & 1.01 & $\begin{array}{l}-0.71 \\
\text { T-not rejected }\end{array}$ & $\begin{array}{l}\text { Non-significant factor affecting } \\
\text { labor productivity }\end{array}$ \\
\hline 39 & $\begin{array}{l}\text { No health worker on the } \\
\text { site }\end{array}$ & 85.71 & 14.29 & 0.74 & $\begin{array}{l}4.80 \\
\text { T-rejected }\end{array}$ & $\begin{array}{l}\text { More than } 50 \% \text {, suggests } \\
\text { significant factor affecting labor } \\
\text { productivity }\end{array}$ \\
\hline 40 & $\begin{array}{l}\text { Awareness of Covid-19 } \\
\text { protocol }\end{array}$ & 25.00 & 75.00 & 0.94 & $\begin{array}{l}-2.65 \\
\text { T-not rejected }\end{array}$ & $\begin{array}{l}\text { Non-significant factor affecting } \\
\text { labor productivity }\end{array}$ \\
\hline 41 & $\begin{array}{l}\text { Improper observance of } \\
\text { Covid-19 protocol }\end{array}$ & 71.43 & 28.57 & 1.06 & $\begin{array}{l}2.02 \\
\text { T-not rejected }\end{array}$ & $\begin{array}{l}\text { More than } 50 \% \text {, suggests } \\
\text { significant factor affecting labor } \\
\text { productivity }\end{array}$ \\
\hline 42 & $\begin{array}{l}\text { No safety engineer on } \\
\text { site }\end{array}$ & 95.67 & 4.33 & 1.01 & $\begin{array}{l}4.51 \\
\text { T-rejected }\end{array}$ & $\begin{array}{l}\text { More than } 50 \% \text {, suggests } \\
\text { significant factor affecting labor } \\
\text { productivity }\end{array}$ \\
\hline 43 & $\begin{array}{l}\text { Unsafe } \\
\text { conditions }\end{array}$ & 79.67 & 20.33 & 1.07 & $\begin{array}{l}2.77 \\
\text { T-rejected }\end{array}$ & $\begin{array}{l}\text { More than } 50 \% \text {, suggests } \\
\text { significant factor affecting labor } \\
\text { productivity }\end{array}$ \\
\hline 44 & Inadequate safety plan & 34.00 & 66.00 & 1.07 & $\begin{array}{l}-1.49 \\
\text { T-not rejected }\end{array}$ & $\begin{array}{l}\text { Non-significant factor affecting } \\
\text { labor productivity }\end{array}$ \\
\hline 45 & $\begin{array}{l}\text { Lack of laborer's safety } \\
\text { standard }\end{array}$ & 81.35 & 18.65 & 0.90 & $\begin{array}{l}3.48 \\
\text { T-rejected }\end{array}$ & $\begin{array}{l}\text { More than } 50 \% \text {, suggests } \\
\text { significant factor affecting labor } \\
\text { productivity }\end{array}$ \\
\hline 46 & $\begin{array}{l}\text { Lack of Health \& safety } \\
\text { provisions }\end{array}$ & 63.56 & 36.44 & 1.08 & $\begin{array}{l}1.26 \\
\text { T-not rejected }\end{array}$ & $\begin{array}{l}\text { Non-significant factor affecting } \\
\text { labor productivity }\end{array}$ \\
\hline \multicolumn{7}{|c|}{ VII. Motivation factors } \\
\hline 47 & Late payment of salary & 55.35 & 44.65 & 0.96 & $\begin{array}{l}0.56 \\
\text { T-not rejected }\end{array}$ & $\begin{array}{l}\text { Non-significant factor affecting } \\
\text { labor productivity }\end{array}$ \\
\hline
\end{tabular}




\begin{tabular}{|c|c|c|c|c|c|c|}
\hline 48 & $\begin{array}{l}\text { Low amount of pay } \\
\text { (underpaid) }\end{array}$ & 75.67 & 24.33 & 0.98 & $\begin{array}{l}2.61 \\
\text { T-rejected }\end{array}$ & $\begin{array}{l}\text { More than } 50 \% \text {, suggests } \\
\text { significant factor affecting labor } \\
\text { productivity }\end{array}$ \\
\hline 49 & Little or no welfare & 68.75 & 31.25 & 0.86 & $\begin{array}{l}2.17 \\
\text { T-not rejected }\end{array}$ & $\begin{array}{l}\text { More than } 50 \% \text {, suggests } \\
\text { significant factor affecting labor } \\
\text { productivity }\end{array}$ \\
\hline 50 & $\begin{array}{l}\text { Little or no financial } \\
\text { rewards }\end{array}$ & 45.60 & 54.40 & 0.74 & $\begin{array}{l}-0.59 \\
\text { T-not rejected }\end{array}$ & $\begin{array}{l}\text { Non-significant factor affecting } \\
\text { labor productivity }\end{array}$ \\
\hline 51 & $\begin{array}{l}\text { Lack of labor recognition } \\
\text { program }\end{array}$ & 73.68 & 26.32 & 0.82 & $\begin{array}{l}2.90 \\
\text { T-rejected }\end{array}$ & $\begin{array}{l}\text { More than } 50 \% \text {, suggests } \\
\text { significant factor affecting labor } \\
\text { productivity }\end{array}$ \\
\hline 52 & $\begin{array}{l}\text { Poor condition of } \\
\text { Bunkhouse }\end{array}$ & 57.14 & 42.86 & 1.14 & $\begin{array}{l}0.63 \\
\text { T-not rejected }\end{array}$ & $\begin{array}{l}\text { Non-significant factor affecting } \\
\text { labor productivity }\end{array}$ \\
\hline 53 & $\begin{array}{l}\text { Lack of place for eating \& } \\
\text { resting }\end{array}$ & 78.57 & 21.43 & 1.35 & $\begin{array}{l}2.12 \\
\text { T-not rejected }\end{array}$ & $\begin{array}{l}\text { More than } 50 \% \text {, suggests } \\
\text { significant factor affecting labor } \\
\text { productivity }\end{array}$ \\
\hline
\end{tabular}

\section{Conclusion}

Based on the foregoing results and discussion, a good understanding the construction labor productivity losses during the Covid-19 pandemic is essential so that the contractors and the government agencies could adjust what would be needed to regain from their losses. In Cagayan Valley Region, including other regions nationwide, and countries worldwide in general, are experiencing the pandemic's effect causing huge profit losses in the construction industries. The number of projects is reduced, specifically in the study area. The laborers of the construction industries are too much affected due to the disease because the local governments imposed the so-called Enhance Community Quarantine (ECQ) to avoid the possibility of spreading the Coronavirus.

Likewise, it is evident from the results of the study that there was laxity on the health protocols. No health worker in the project site ranked the highest in the health \& safety factor group with an RII of 0.97 and ranked 1st among 53 influencing factors on the different groups. It means there was laxity on the Covid-19 protocols. Another alarming result, there was no safety engineer assigned in the projects and ranked 2nd with an RII of 0.93 . Besides, among all the 7 groups of factors, health and safety group ranked 1st with 0.81 , followed by the schedule compression group with an RII of 0.78. Hence, these two groups of factors have a strong relationship. The contractors reduced their number of workers, but they increased the number of working days, including Saturdays, to cope with their target schedule of highway construction activities. Hypothesis testing proved that working six days per week was one of the significant factors affecting labor productivity during the pandemic, as suggested by more than $50 \%$ of the respondents. As it can be seen that workforce group of factor with RII of 0.77 , indicated slight difference with schedule compression group. It means these two groups of factors have strong inter-relationships influencing labor productivity.

On the other hand, the materials and equipment group and management team ranked 4th and 5th with RII of 0.72 and 0.71 among the seven groups of factors. It shows these two groups of factors also have a strong inter-relationship because of slight differences. The poor condition of equipment \& tools is evident in its effect on the labor low productivity during the pandemic. In contrast, the supervision and motivation groups of factors are the lowest-ranked groups. There was no significant effect on the low productivity, as suggested by more than $50 \%$ of respondents in the study area.

\section{Compliance with ethical standards}

\section{Acknowledgments}

Thanks go to my son Mr. Karl Louie \& my daughter Ms. Kimberly Claydel, and Engr. Allan Aguda for their helped in distributing and collecting the questionnaires survey. Special thanks to the International Institute of Cambodia University of Technology, and GRADXS by facilitating the study program. 


\section{Disclosure of conflict of interest}

The authors, whose name appears in this article, disclosed no conflict of interest with any organization.

\section{Statement of ethical approval}

The present research work does not contain any studies performed on animals or human subjects by any of the authors.

\section{Statement of informed consent}

Informed consent was obtained from all individual participants included in the study.

\section{References}

[1] Koźlak A. Role of the Transport System in Stimulating the Economic and Social Development. Transport Economics and Logistics. 2017; 72: 19-33; Doi:10.5604/01.3001.0010.6873.

[2] McTague B, Jergeas G. Productivity Improvements on Alberta Major Construction Projects, Construction Productivity Improvement Report/Project Evaluation Tool. Alberta Economic Development, Alberta, Canada. 2002.

[3] Alaghbari W, Al-Sakkaf AA, Sultan B. Factors Affecting Construction Labor Productivity in Yemen, Intl. Journal of Construction Management. 2017; 1-13 Doi.10.1080/15623599.2017.1382091

[4] Natawidjana R, Nurasiyah R. Study of labor cost escalation in delay projects; presented at the Intl. Conference on Innovation in Research. 2020. Doi:10.1088/1742-6596/1469/1/012034.

[5] Naoum SG. Factors influencing labor productivity on construction sites: A state-of-the-art literature review and a survey. International Journal of Productivity and Performance Management. 2016; 65(3):401-421. DOI: 10.1108/IJPPM-03-2015-0045.

[6] Nyando CK, Strasheim JA. Assessing Labor-based Construction Works Management Processes. Proceedings of the Institution of Civil Engineers - Management, Procurement and Law. 2012; 164(4): 239-251.

[7] Hicksona BG, Ellis A. Factors affecting Construction Labor Productivity in Trinidad and Tobago. The Journal of the Association of Professional Engineers of Trinidad and Tobago. 2014; 42: 4-11.

[8] Irfan M, Zahoor H, Abbas M, Ali Y. Determinants of Labor Productivity for Building Projects in Pakistan. Journal of Construction Engineering, Management \& Innovation. 2020; 3(2): 85-100. Doi: 10.31462/jcemi.2020.02085100.

[9] Low SP, Chan YM. Managing Productivity in Construction. JIT Operations and Measurements, Brookfield (VT). 1997.

[10] Thomas HR, Daily J. Crew Performance Measurement via Activity Sampling. Journal of Construction Engineering and Management. 1983; 109(3): 309-320.

[11] Banik GC. Construction productivity improvement. In Proceedings of the 35th ASC Annual Conference, San Luis Obispo, CA. 1999: 165-178.

[12] Dabirian S, Khanzadi M, Taheriattar R. Qualitative Modeling of Sustainability Performance in Construction Projects Considering Productivity Approach. International Journal of Civil Engineering. 2017; 15(8): 1143-1158.

[13] Al-Shahri M, Assaf S, Atiyah S, AbdulAziz A. The management of construction company overhead costs." International Journal of Project Management. 2001; 19: 295-303.

[14] Cronbach, L. Coefficient alpha and the internal structure of test. Psychometrica. 1951; 16: 297-334.

[15] Mekdim M. A Study on Construction Equipment Planning and Management Problems in Road Construction Project. A Case Study: The Addis Ababa City Roads Authority. 2017. [Unpublished].

[16] George D. SPSS for Windows Step by Step: A simple guide and reference. 11.0 update (4th ed.). Allyn \& Bacon. 2003.

[17] Gliem JA. Calculating, Interpreting, and Reporting Cronbach's Alpha Reliability Coefficient for Likert-type Scales. 2003. 
[18] Hedaoo H. Delay Analysis by Using Relative Importance Index Method in Infrastructure Projects. Int. J. Civil Engg. Conc.Structs. 2016.

[19] Dong Z. The Relationship Between Information Technology and Construction Productivity. University of Kentucky Doctoral Dissertations. 2010; 44. Http://Uknowledge.Uky.Edu/Gradschool_Diss/44

[20] Hafez SM, Aziz RF, Morgan ES, Abdullah MM, Ahmed EK. Critical Factors Affecting Construction Labor Productivity in Egypt. American Journal of Civil Engineering. 2014; 2(2): 35-40. Doi: 10.11648/j.ajce.20140202.14.

[21] Olomolaiye P, Kaming P, Holt G, Harris F. Factors influencing craftsmen's productivity in Indonesia. International Journal of Project Management. 1996: 21-30. 